\title{
Seasonal and spatial patterns of mudblister worm Polydora websteri infestation of farmed oysters in the northern Gulf of Mexico
}

\author{
Sarah M. Cole ${ }^{1,2}$, Kelly M. Dorgan ${ }^{1,2, *}$, William Walton ${ }^{2,3}$, Brian Dzwonkowski ${ }^{1,2}$, \\ Jeffrey Coogan ${ }^{1,2}$ \\ ${ }^{1}$ University of South Alabama, Department of Marine Sciences, Mobile, AL 36688, USA \\ ${ }^{2}$ Dauphin Island Sea Lab, 101 Bienville Blvd, Dauphin Island, AL 36528, USA \\ ${ }^{3}$ Auburn University Shellfish Laboratory (AUSL), 150 Agassiz Street, Dauphin Island, AL 36528, USA
}

\begin{abstract}
Mudblister worms Polydora websteri bore holes into oyster shells, and oysters respond by secreting extra layers of shell, creating a mudblister. When shucked, mudblisters can burst and release anoxic mud. Thus, infestation devalues oysters, particularly on the half-shell market. This study quantified oyster condition index and worm abundances over 2 full growing seasons at commercial oyster farms on the US Gulf of Mexico coast, and our results indicate that oyster growth rate, manipulated through ploidy and stocking densities, had little effect on worm infestation. Larval spionid worms were found year-round. Larval abundances were slightly higher within than away from farms, and larval size distributions were skewed toward smaller larvae within the farms, suggesting that farms may be a source of larvae. Triploid oysters had higher or comparable condition index values to diploids, but during summer months, when worm infestation was high, worm infestation was not correlated with condition index. Previously infested shells deployed at farms became more infested than uninfested shells at moderate infestation levels, but re-infestation was influenced more by farm location than by previous infestation condition. Higher infestation at a farm with more variable salinity as well as higher infestation in 2017 when salinity was lower suggest that salinity may be a potential driver of mudblister worm infestation. Results indicate that oyster farmers on this coast should use desiccation to treat oysters for mudblister worms frequently during the summer, but that manipulating stocking density or ploidy is unlikely to be effective in preventing mudblister worm infestation.
\end{abstract}

KEY WORDS: Oyster aquaculture - Gulf of Mexico · Oyster · Shellfish • Biofouling · Spionidae · Oyster farming $\cdot$ Crassostrea virginica

\section{INTRODUCTION}

Infestation by spionid worms occurs world-wide in a variety of shellfish species including oysters, mussels, scallops, and abalone (Lunz 1940, Haigler 1969, Wargo \& Ford 1993, Caceres-Martinez et al. 1998, Read 2010). Spionid worms that bore into shellfish hosts primarily belong to the 'Polydora-complex' which includes Polydora, Psuedopolydora, and Boccardia spp. (hereafter referred to as 'Polydora') (Blake 1969b). Most Polydora settle in crevices in the

${ }^{*}$ Corresponding author: kdorgan@disl.org shell surface and secrete a mucous acid to dissolve the surface of the shell and create U-shaped burrows which are then filled with detritus collected by the worm (Haigler 1969, Zottoli \& Carriker 1974, Read 2010). Over time, these burrows can penetrate through the shell and irritate the host (Lunz 1941, Haigler 1969, Zottoli \& Carriker 1974, Lauckner 1983). In response, the oyster secretes a conchiolin protein layer followed by layers of calcite over the worm's mud tubes, creating a mud-filled blister (Lunz 1941, Haigler 1969). Mudblisters can also be created

() The authors 2020. Open Access under Creative Commons by Attribution Licence. Use, distribution and reproduction are unrestricted. Authors and original publication must be credited. 


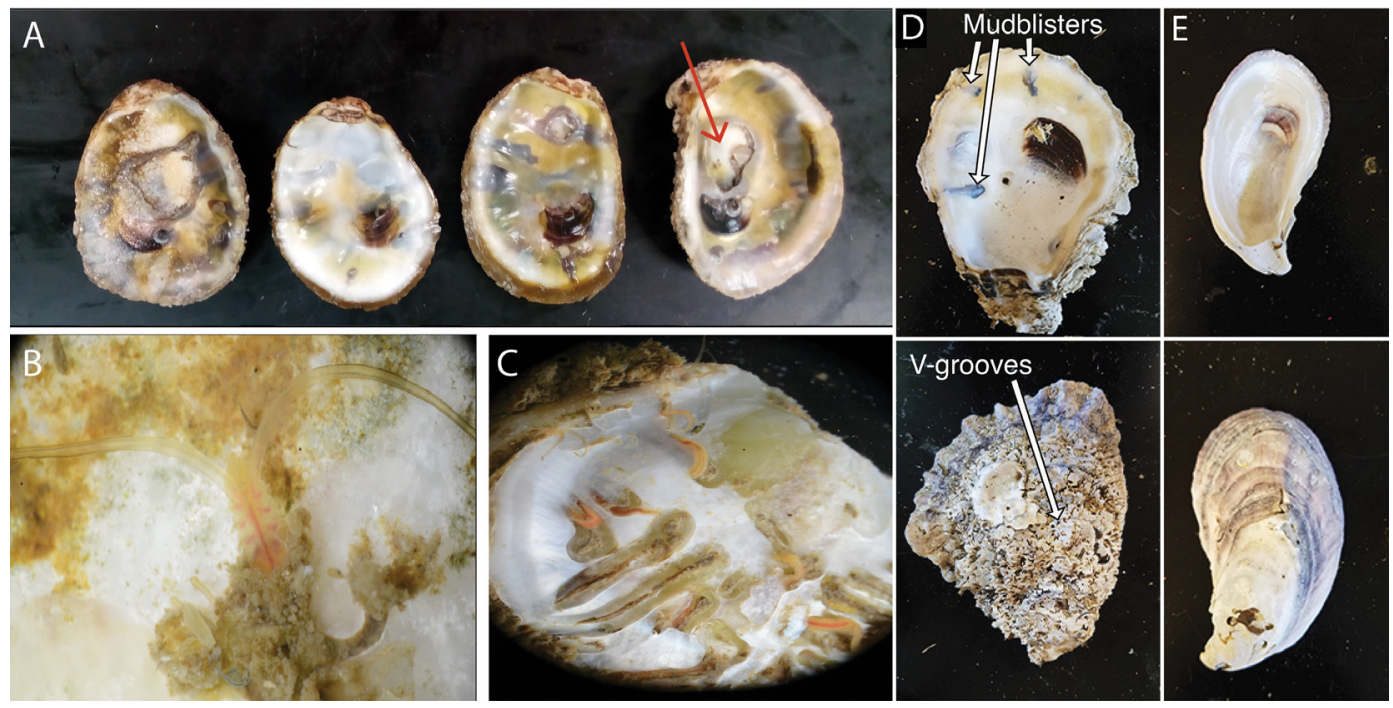

Fig. 1. (A) Oyster shells with a high prevalence of mudblisters. Arrow on the far-right shell shows a popped mudblister; (B) head of Polydora websteri with palps extended protruding from mud burrow inside of oyster shell; (C) inside of broken oyster shell showing U-shaped burrows of $P$. websteri lined with detritus and mud; (D) previously infested oyster shell with presence of mudblisters and abundance of V-shaped grooves; (E) previously uninfested oyster shell with no mudblisters and few V-shaped grooves

when Polydora settle at the edge of the shell lip and create a mud tube that extends beyond the edge of the oyster shell, agitating the host until a thin layer of shell is grown to create a barrier; the infesting worms then fill the cavity with compacted mud (Lauckner 1983, Nell 2007) (Fig. 1A-C).

Current methods for treating infestation by Polydora in aquaculture include immersion in freshwater, brine dips, and exposure to $70^{\circ} \mathrm{C}$ water (Mackin \& Cauthron 1952, Nel et al. 1996, Dunphy et al. 2005, Nell 2007, Brown 2012, Morse et al. 2015). Periodic drying of oysters, e.g. leaving oysters at intertidal levels or flipping floating oyster cages, also helps prevent or reduce infestation of mud worms (Littlewood et al. 1992, Ghode \& Kripa 2001, Gamble 2016). Gamble (2016) found that infestation by $P$. websteri Hartman in Loosanoff \& Engle (1943) was significantly lower when floating oyster cages were flipped weekly versus biweekly to expose oysters to air for $\sim 24 \mathrm{~h}$. Cool-air storage of oysters for a prolonged period (at least $10 \mathrm{~d}$ ) has resulted in 100\% mortality of $P$. websteri with limited mortality of oysters (Brown 2012, Morse et al. 2015). While these methods may be effective at limiting infestation of Polydora, they are often time consuming, labor intensive, costly, and can decrease shellfish growth and increase host mortality (Littlewood et al. 1992, Nel et al. 1996).

The aim of the current study was to provide actionable information to oyster growers about how to best avoid or reduce mudblister worm infestation. The effect of variables hypothesized to affect mudblister infestation (seasonal and spatial variability, stocking density, ploidy, oyster growth rate, environmental variables; see Table 1) were explored, as well as the implications of infestation to oyster condition index and potential for re-infestation.

Triploid oysters are increasingly popular in farmed aquaculture due to their higher growth rates (Stone et al. 2013, Walton et al. 2013, Wadsworth et al. 2019). This is, in part, due to them having a third chromosome, which causes them to be infertile. Instead of investing energy in producing gametes and spawning as diploids do, this energy can be applied to increased growth (Baker \& Mann 1991, Guo \& Allen 1994, Stone et al. 2013, Walton et al. 2013). Over $85 \%$ of the oyster seed sold by the Auburn University Shellfish Laboratory (AUSL) to farmers along the Alabama coast in 2017 were triploid (S. Rikard pers. comm.). Several farmers had noted that their triploid oysters appeared to have a lower incidence of mudworm infestation (W. Walton pers. comm.), but the effect of faster growth due to ploidy on Polydora infestation has not been studied. In addition to selecting ploidy, farmers also alter stocking density of oysters. Stocking oysters at a higher density allows farmers to grow more oysters per cage; however, oysters at low stocking density typically have faster growth rates due to decreased competition and reduced physical damage from proximity to other oysters (Honkoop \& Bayne 2002, Bishop \& Hooper 2005). Higher stocking densities may also reduce the effectiveness of air drying as a tool to control bio-fouling, including mudblister worms. Reduced 
flow through bags with higher densities of oysters may allow larval worms more opportunity to recruit once within the oyster bag. Here, we assessed the effects of stocking density and ploidy on worm infestation and oyster health.

Another goal of this study was to provide information for farmers, particularly in the northern Gulf of Mexico, for making informed decisions about when to expect and treat Polydora infestation on their farms, based on seasonal patterns and environmental conditions favorable for worm infestation. Previous studies have observed infestation of Polydora (Littlewood et al. 1992, Nel et al. 1996, Handley \& Bergquist 1997, Ghode \& Kripa 2001, Dunphy et al. 2005, Brown 2012), but few studies have investigated how abiotic conditions impact infestation rates in farmed oysters in the Gulf of Mexico, especially on long-term deployments of oysters (>3 mo). Here, we aimed to quantify seasonal and spatial patterns of Polydora infestation along the Alabama coast and determine whether these patterns correlated with environmental factors (temperature, salinity, dissolved oxygen [DO], and turbidity). Lunz (1941) and Loosanoff \& Engle (1943) suggested that Polydora prefer low salinity based on higher infestation observed in areas with lower salinity; however, Owen (1957) found higher infestation at sites with high salinity throughout the year. Nell (2002) and Clements et al. (2017) found that increased siltation and sediment on oysters increased $P$. websteri infestation. $P$. websteri use palps to capture suspended particles or sediments deposited near their burrows. Increased sedimentation can negatively affect oysters by clogging their gills, reducing their rate of water pumping, and increasing the amount of psuedofeces produced (Loosanoff 1962). This stress may reduce the ability of oysters to secrete new layers of shell to recover from infestation. Thus, as turbidity increases, we hypothesized that $P$. websteri abundance may increase as well.

We also sought to determine whether infested farms may act as sources or sinks for Polydora larvae. This question is challenging to address, as larvae of $P$. websteri are difficult to distinguish morphologically from larvae of other Spionidae. Here, we quantified the temporal and spatial distribution of planktonic larvae of spionid polychaetes adjacent to and away from oyster farms to determine if farms are potential sources of mudblister worms. Kim et al. (2010) found an increase in Crassostrea virginica larvae settlement from east to west in Mobile Bay that is consistent with larval transport patterns. P. websteri may follow a similar pattern of transport and settlement, which would lead to a lower $P$. websteri abundance at farms on the eastern side of Mobile Bay. Most dispersal occurs during the planktonic life stage for marine invertebrates (Pechenik 1999) but dispersal distances are not necessarily long (Shanks 2009). $P$. websteri broadcast larvae into the water column from broods held in burrows, and larval duration is known to be longer than 1 d (Hopkins 1958, Blake 1969a, Zottoli \& Carriker 1974). Larvae are released with 3 setigers and metamorphose and settle at 17 setigers (Hopkins 1958, Blake 1969a, Zottoli \& Carriker 1974, Read 2010). Initial larval stages of $P$. websteri are photopositive (attracted to light) (Blake 1969b, Ye et al. 2017), so larvae are likely to be transported with surface currents; this adaptation may dilute larvae and transport them away from oyster farms. We hypothesized that farms are sources of $P$. websteri, in which case larval abundances within farms would be higher and skewed toward more recently released larvae $(\sim 3$ setigers $)$ than a short distance away. We also hypothesized that larval abundances would be directly related to adult abundances. Zajac (1991) found that total fecundity, and thus larval abundances, in P. cornuta (the accepted name for P. ligni; WoRMS Editorial Board 2019) was higher in the summer when adult density was high.

In this study, we also tested the hypothesis that high worm infestation would have detrimental effects on oyster health, specifically whether it decreased oyster condition index. Condition index is a measure of oyster tissue weight relative to total weight. High condition index is used to assess health; however, condition index follows a seasonal cycle with gametogenesis and declines following spawning, so a low condition index does not necessarily mean that an oyster is in poor health (Lawrence \& Scott 1982, Abbe \& Sanders 1988, Abbe \& Albright 2003). There is no clear consensus in the literature on whether Polydora infestation affects condition. Wargo \& Ford (1993) found a negative correlation between condition index and percent Polydora blister coverage when collected in December. Likewise, Handley (1998) found a negative correlation between various condition index measurements (flesh, oocyte, gonad) and percent shell blistered by Polydora, with the highest decrease in oyster oocytes from oysters with greater than $50 \%$ shell coverage. Mackin \& Cauthron (1952) found that meat damage was greater in heavily infested oysters during the summer, and they attributed this to $P$. websteri infestation. In contrast, Caceres-Martinez et al. (1998) found no correlation between condition index and blister area or blister number over a full season of growth, and Loosanoff \& Engle (1943) found that regardless of Polydora infestation, all oysters were in healthy condition. 
Lastly, the benefits of treating infested oysters to remove Polydora may depend on whether worms preferentially re-infest previously infested shells. Polydora secrete an acidic mucous to bore into shells and create Ushaped burrows (Haigler 1969, Zottoli \& Carriker 1974), an energetically costly and time-consuming process ( 1 $\mathrm{wk}_{\text {; }}$ Haigler 1969). Treatment against infestation (air drying, freshwater and brine dips) kills worms but leaves uninhabited burrows. Reinfestation may occur more rapidly or may be more severe if worms move into these previously occupied burrows rather than expending energy to create new burrows. Polydora may also respond to cues left behind by previous inhabitants. Larvae of the related $P$. ligni have been found to settle near the tubes of adults (Blake 1969a), and Simon et al. (2006) found that the related Boccardia sp. were often found within burrows made by Polydora and Dipolydora, suggesting that larvae may settle into existing burrows. Here, we tested the hypothesis that previous infestation by $P$. websteri facilitates re-infestation of oysters. Support for this hypothesis would provide greater incentive for farmers to treat oysters more frequently to prevent established infestations.

We addressed these diverse goals through two 1 yr long deployments of oysters, C. virginica (Gmelin, 1791) at farms along the Alabama coast in the US Gulf of Mexico to quantify $P$. websteri infestation and effects on oyster condition due to differences in stocking density, ploidy, season, and location (Table 1). Water samples were collected within and away from farms to determine abundances and sizes

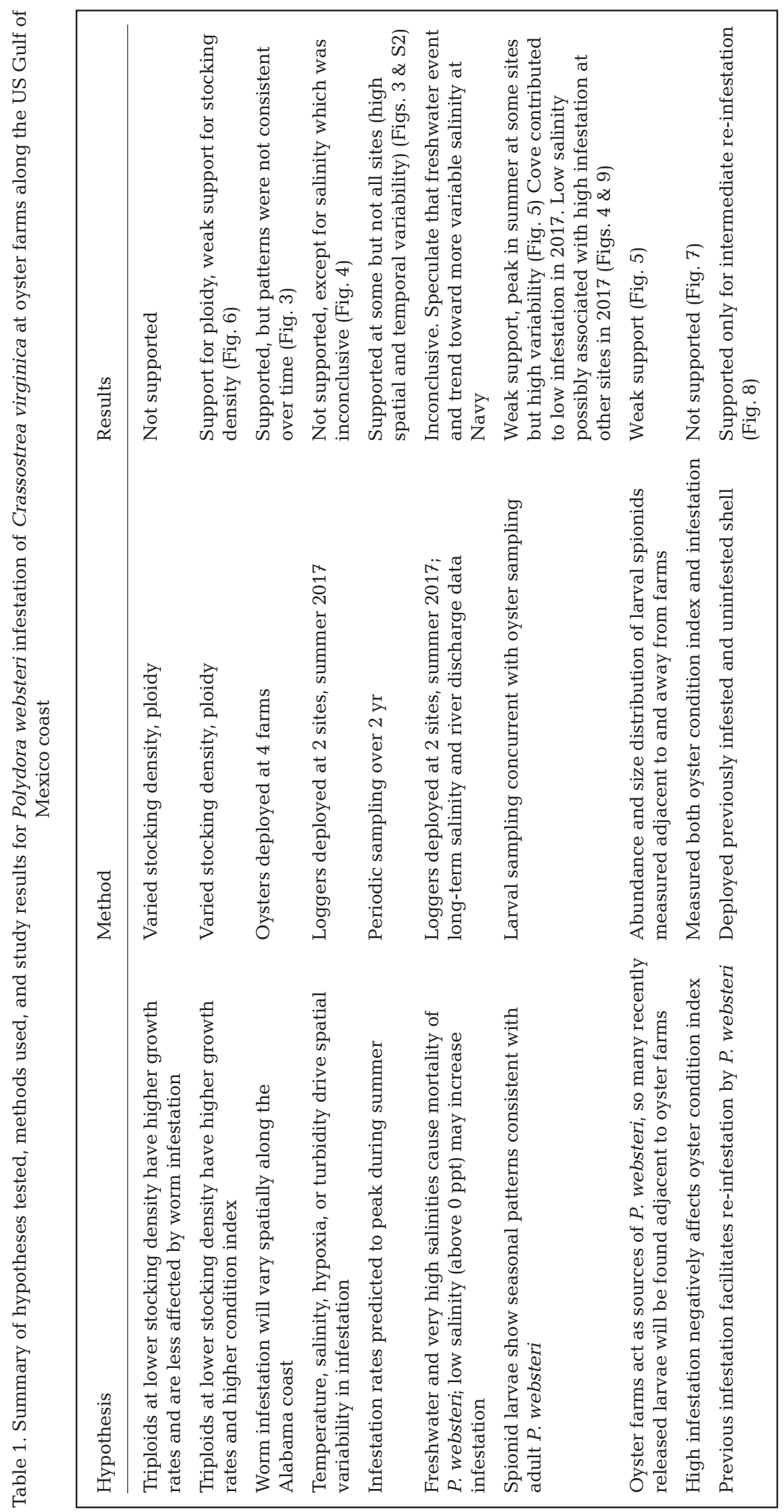


of spionid larvae (P. websteri planktonic larvae are difficult to distinguish from those of other species in the family Spionidae). Based on the findings of the first year-long deployment, a short-term deployment with more frequent sampling was conducted during the summer when infestation rates were highest. Temperature, salinity, DO, and turbidity were measured continually to examine correlations that might suggest possible drivers of $P$. websteri infestation, and shells that had been previously heavily or lightly infested were deployed to determine if $P$. websteri preferentially re-infest previous burrows.

\section{MATERIALS AND METHODS}

\subsection{Long-term deployments}

To test the effects of ploidy and stocking density on Polydora websteri infestation as well as the effects of infestation on oyster health (condition index), longterm deployments were conducted at 4 oyster farms across the coast of Alabama, USA (Fig. 2): Murder Point Oyster (Murder Point), Point aux Pins LLC (Point aux Pins), Massacre Island Oyster Ranch (Massacre Island), and Navy Cove Oyster Farm (Navy Cove). These sites were sampled every 2-3 mo over $1 \mathrm{yr}$ (ensuring that oysters had reached harvestable size, $>75 \mathrm{~mm}$, and to cover seasonal variability) to determine seasonal and spatial variability in infestation and oyster condition index. Diploid and triploid eastern oyster Crassostrea virginica spat $(25.4 \pm 3.3 \times$ $10.2 \pm 1.8 \mathrm{~mm}$ ) from the AUSL hatchery were deployed in November 2015 (2016 deployment) and

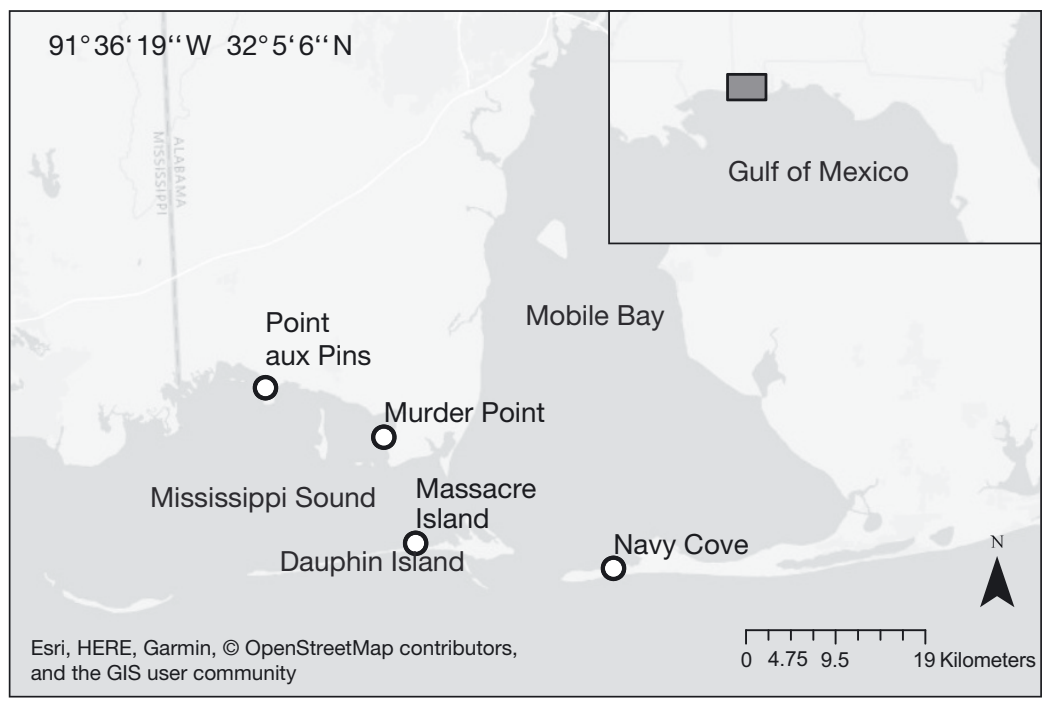

Fig. 2. Study area with oyster farms (white circles) where oysters were deployed
August/September 2016 (2017 deployment) with final collection in August/September 2016 and May 2017, respectively. Oysters were deployed at high (600), medium (300), and low (150) stocking densities in plastic mesh bags $(91 \times 46 \times 10 \mathrm{~cm})$ inside OysterGro $^{\mathrm{TM}}$ floating cages with 4 bags per cage and a total of 8 cages at each farm. Medium stocking density was chosen based on current typical stocking recommendations for Alabama farmers (Davis et al. 2013). In total, 4 bags of each of the 6 treatments (ploidy $x$ stocking density) were randomly assigned to cages. Oyster farmers were asked to treat research oysters as they did the rest of their farm. Farms were selected to include sites representative of farming conditions typical in Alabama and the northern Gulf of Mexico in which farmers were willing to participate in the study. Farmers flipped cages out of water periodically, but the duration and frequency varied among farms according to participating farmers' methods. Thus, sites differed both spatially and in farmer practices. All farms were located subtidally in $\sim 1 \mathrm{~m}$ depth; the tidal range was $<1 \mathrm{~m}$. After $2-3 \mathrm{mo}$, the stocking density in each bag was split in half to account for growth of oysters, dropping stocking densities to 300 , 150, and 75 for high, medium, and low densities, respectively.

Oysters from each treatment (12 during 2016 deployment, 4 during 2017 deployment) were haphazardly sampled to measure condition index. To assess worm infestation, one oyster was haphazardly sampled from each bag at each farm every 2-3 mo for a total of 4 replicates for each treatment at each farm. After each sampling, additional oysters were removed from medium- and high-density bags to maintain stocking density proportions across all treatments. During the August/ September sampling of the 2016 deployment, only Massacre Island and Point aux Pins were sampled; oysters at Murder Point and Navy Cove were harvested in June 2016 due to their large size and cage constraints. Sampled oysters were transported back to the lab on ice and either refrigerated and treated to extract worms within 2 $\mathrm{d}$ of collection or frozen and later analyzed for condition index.

To extract $P$. websteri from the shells, oysters were placed in a vermifuge solution of $100 \mathrm{ppm}$ o-dichlorobenzene and $500 \mathrm{ppm}$ phenol in saltwater ( $20 \mathrm{ppt})$ for $24 \mathrm{~h}$ at room temperature following methods adapted from Mac- 
Lenzie \& Shearer (1959). We found that worm counts were high after $6 \mathrm{~h}$ and did not increase appreciably between 6 and $24 \mathrm{~h}$. While we cannot be certain that we counted $100 \%$ of the worms, any underestimation should have affected all oysters similarly so should not bias our results. During and after extraction, worms were carefully pulled from their burrows, placed in $7.5 \% \mathrm{MgCl}_{2}$ to relax the muscles (to be able to later measure body size-data not shown), and preserved in 95\% ethanol. After extraction, oysters were removed from solution. Some worms only emerged part-way from their burrows; these were counted using a microscope, and then the whole oyster was frozen for condition index. Preserved $P$. websteri extracted from each oyster were later counted under a microscope. Because worms sometimes fragment into multiple pieces, only $P$. websteri (whole individuals or fragments) with heads were counted as individuals. Identification of $P$. websteri was performed based on morphology described by previous studies (Hopkins 1958, Blake 1969b, Haigler 1969). P. websteri have been previously identified in oysters from Alabama oyster farms near Murder Point using the same morphological criteria and then confirmed with DNA sequencing (Rice et. al 2018). We did not closely examine every worm, so cannot discount the possibility that other species of mudblister worms may have occurred in small numbers. Because oysters varied in size (e.g. diploids smaller than triploids), worm abundances were normalized to shell area to compare across treatments, but analyses on uncorrected worm abundances showed similar results.

Water samples for spionid larvae were taken in conjunction with oyster sampling. Three replicate samples were taken both inside the oyster farm next to oyster bags ('adjacent') and approximately $50 \mathrm{~m}$ away from the oyster farms ('away') at each location. Away locations were chosen at a distance roughly $50 \mathrm{~m}$ from oyster farms to keep depth and bottom type similar for adjacent and away samples. Water samples were not taken in March 2017 at Massacre Island and Navy Cove. Water samples were taken with a 51 Niskin bottle and sieved through a $20 \mu \mathrm{m}$ nylon mesh in the field. Sieved samples were preserved in $95 \%$ ethanol. Identification of larvae was made to family level, Spionidae (Polychaeta), and number of setigers of each larva was recorded and used as a proxy for larval age. Larvae were counted following methods adapted from Marsden (1992): $1 \mathrm{ml}$ subsamples were examined using a compound microscope and Sedgewick-Rafter cell, and 20\% or greater of the total sample volume was subsampled for counts.
Condition index was calculated for all oysters sampled, including the $P$. websteri-extracted oysters. The whole wet weight of each oyster was measured after cleaning off mud, barnacles, and other biofouling organisms. The oysters were then opened and the soft tissue was separated from the shell and measured for wet tissue weight and dried tissue weight after $48 \mathrm{~h}$ in a drying oven at $80^{\circ} \mathrm{C}$. Processed shells were air-dried at room temperature for the same period. After $48 \mathrm{~h}$, dry shell weight and dry tissue weight were recorded for each oyster. Condition index was then calculated using the gravimetric formula (Lawrence \& Scott 1982, Abbe \& Albright 2003):

$$
\text { Condition index }=\frac{\text { Dry tissue weight }}{\begin{array}{l}
\text { Whole wet weight }- \\
\text { Dry shell weight }
\end{array}} \times 100
$$

Shell length and width were measured for each oyster and used to find an approximate pseudo-area (based on an ellipse) for each oyster that was extracted, and $P$. websteri abundance was calculated and normalized by pseudo-area for each oyster (ind. $\mathrm{cm}^{-2}$ ). This normalization was made to better compare infestation of oysters that differed substantially in size by the end of the experiment.

For statistical analyses, 4-way ANOVAs were used for $P$. websteri abundance (ind. $\mathrm{cm}^{-2}$ ) and condition index as dependent variables and stocking density, ploidy, collection date, and oyster farm location as categorical independent variables. P. websteri abundance (ind $\mathrm{cm}^{-2}$ ) was cube-root transformed to obtain a normal distribution. The final sampling of the 2016 deployment was excluded from this analysis because samples were only taken from Massacre Island and Point aux Pins. Instead, a separate 3-way ANOVA (with density, ploidy, and oyster farm location as independent variables) was used for the August/ September 2016 sampling date. Collection date was modeled as a categorical rather than continuous effect because we did not expect seasonal patterns to be linear; rather, we were trying to identify peaks. It is possible that adjacent dates were correlated, but sampling dates were few and the duration between dates was long relative to the settlement time of worms (see Section 3.1). When significant differences were found, multiple comparison post hoc Tukey tests for pair-wise comparisons were performed. All statistical analyses were conducted in R v.3.4.4 (R Core Team 2016).

A 3-way ANOVA was used to test the effects of collection date, oyster farm location, and proximity to farm as independent variables on spionid polychaete larvae (ind. $1^{-1}$ ). Data for March 2017 were excluded 
from this analysis, because samples were not taken at Massacre Island and Navy Cove during this collection period. Instead, a separate 2-way ANOVA (with oyster farm location and proximity to farm as independent variables) was run the March 2017 sampling date. When significant differences were found, multiple post hoc Tukey tests for pair-wise comparisons were performed. To determine whether the distribution of larval size (number of setigers) differed, a nonparametric 2-way Scheirer-Ray-Hare test was utilized with collection date and proximity to farm as independent variables. When significant differences were found, a post hoc Dunn Kruskal-Wallis multiple comparison with adjusted p-values using the BenjaminiHochberg method was performed (Ogle et al. 2018).

To determine whether adult $P$. websteri and larval spionid polychaete abundances were correlated, a Kendall Tau test was conducted. To determine whether condition index and $P$. websteri abundance were correlated, Kendall Tau tests were conducted on ranked data from individual oysters. This non-parametric test was selected because of the small sample size $(<100)$ and non-normal distribution of P. websteri abundance data.

\subsection{Short-term deployment}

To further test seasonal and spatial variability of worm infestation, we extended the 2017 deployment and sampled oysters more frequently during the summer when infestation had been high during 2016 (see Section 3.1). Live oysters from the long-term 2017 deployment were re-bagged into 8 bags of each ploidy on 18 May 2017 at Point aux Pins, Massacre Island, and Navy Cove (Fig. 2); all bags were maintained at a stocking density of 50 live oysters.

To test whether worms preferentially settle in oyster shells with burrows from previous infestation, we deployed sun-dried oyster shells of similar size that were either infested or uninfested. Shells were selected from a large number of shells available at AUSL and categorized as either infested ( $\geq 1$ obvious mudblister and an abundance of small V-shaped grooves on the outer surface of the shell indicating worm burrows) or uninfested (no mudblisters and few V-shaped grooves; Fig. 1D,E). Dried shell was used because previous infestation could be assessed and $P$. websteri have been shown to settle on both live and dead shell (Clements et al. 2018). Shells were placed in separate bags (25 shells per bag, lower density than oysters) at the 3 farms in the same floating cages as the live oysters.
Oysters and shells were sampled every $3 \mathrm{wk}$ from May to August 2017 for a total of 5 sampling dates, and $P$. websteri were extracted from burrows, preserved, and counted as previously described. Two oysters and 3 shells of each type were randomly sampled from each bag from the 3 farms at each sampling date. Twelve of the 16 oysters of each ploidy collected were haphazardly chosen for worm extraction. After extraction, photographs were taken of each live oyster, and the planar area of shell was measured using ImageJ v.1.41o (Schneider et al. 2012). Shell area was used to calculate normalized $P$. websteri abundance (ind. $\mathrm{cm}^{-2}$ ). For shells, $P$. websteri abundance was not normalized to shell area because shells of approximately the same size were chosen before deployment.

To determine whether environmental conditions varied among the farms and whether this might affect worm abundances, environmental parameters (salinity, temperature, DO, and turbidity) were measured every $15 \mathrm{~min}$ for the duration of the 2017 shortterm deployment (18 May-22 August 2017) using YSI 6600 sondes deployed at Massacre Island and Navy Cove. Sondes were replaced with clean, calibrated sondes at each collection date. Sondes were attached to pilings in the farm in the middle of the $\sim 1 \mathrm{~m}$ deep water column. Salinity and part of the DO data at Massacre Island were lost for the last collection period due to sensor malfunction. There were several short gaps ( $4 \mathrm{~h}$ or less) in the Massacre Island data that were filled using linear interpolation.

Significance of ploidy, collection date, and oyster farm location on $P$. websteri abundance during this short-term summer deployment was determined with a 3-way ANOVA followed by a post hoc Tukey test when results were significant. All triploid oysters at Navy Cove experienced mortality after the third collection, likely due to a low salinity event, but were included in the analysis because $P$. websteri will settle on shells even if the oysters are not alive (Clements et al. 2018). To determine whether infestation differed between previously infested and uninfested shells and among oyster farms, $P$. websteri abundance $\left(\right.$ shell $^{-1}$ ) data were square-root transformed to obtain a normal distribution. Since we were primarily interested in the effects of infestation treatment and site, a 2-way repeated measures ANOVA was run that corrected for date of collection.

To determine the relationship between environmental data and $P$. websteri abundance, each environmental variable (temperature, salinity, DO, and turbidity) was subsampled into periods between oyster collections for Massacre Island and Navy Cove. 
For temperature, salinity, and DO at each collection period, a Durbin-Watson test was conducted to determine if data were autocorrelated. If data were autocorrelated, Kwiatkowski-Phillips-Schmidt-Shin tests were conducted to determine if data were stationary; if data were not stationary, suitably lagged and iterated differences were taken until stationary (Hyndman 2013). Once data were stationary, a $t$-test for autocorrelated time series was performed as described by O'Shaughnessy \& Cavanaugh (2015) to determine differences between Massacre Island and Navy Cove. These tests were not used for turbidity because we used different turbidity sensors that are not directly comparable, so instead we assessed overall trends (Lewis et al. 2007).

In addition to potential differences among site means, the differences in site variance were examined because we expected that large variability in environmental conditions would have a negative impact on worms and/or oysters. The power spectral densities of the environmental parameters (salinity, temperature, DO) were used to quantify the variance over a broad range of frequencies. The multiple taper method of Thomson (1982) was used to calculate the power spectral densities and the associated 95\% CIs for these geophysical time series using the signal process toolbox in Matlab ${ }^{\circledR}$. Before conducting the analysis, the data were averaged by hour to damp highfrequency noise in the time series and pre-whitened using either a linear trend or constant value.

\subsection{Long-term variability in environmental conditions}

Although we did not collect environmental data at the sites during the summer of 2016, long-term monitoring of environmental data at several sites around Mobile Bay allowed us to compare salinity between years and to put the low salinity event of 2017 in a broader context. Long-term salinity data from a station at Dauphin Island (east of Massacre Island Oyster Farm near the mouth of the bay; Fig. 2) was analyzed from February 2003 to January 2017. Data were collected using YSI 6600s from a fixed, near-bottom ( $0.5 \mathrm{~m}$ above the sea floor) site maintained by the Dauphin Island Sea Lab (http://arcos.disl.org). Data were collected every $30 \mathrm{~min}$, and a $48 \mathrm{~h}$ low pass filter was used to isolate the subtidal salinity changes that occurred at the site. River discharge data were calculated based on 2 US Geological Survey (USGS) gauging stations: the Claiborne L\&D (USGS Stn 02428401) on the Alabama River and Coffeeville L\&D (USGS Stn
02469762) on the Tombigbee River stations. The sum river flow of the 2 stations was used as the total river discharge into Mobile Bay, following Park et al. (2007).

\section{RESULTS}

\subsection{Polydora websteri abundances}

Polydora websteri abundances in the 2016 deployment varied substantially among the farms, with different farms showing higher infestation during the first 3 mo sampled (Fig. 3A). Significant interaction was observed between collection date $\times$ oyster farm location $\left(F_{6,215}=87.72, \mathrm{p}<0.001\right.$; Fig. $\left.3 \mathrm{~A}\right)$ and density $\times$ ploidy $\times$ oyster farm location $\left(F_{4,215}=2.30, \mathrm{p}<0.05\right.$; Fig. S1 in the Supplement at www.int-res.com/articles/ suppl/q012p297_supp.pdf). Infestation was higher during August/September, but only 2 farms were sampled, so these data were evaluated separately (Figs. 3A \& S2). Post hoc pair-wise Tukey tests showed there were no significant differences between ploidies or among stocking densities at individual farms (Fig. S1). P. websteri abundances for August/September 2016 (only Massacre Island and Point aux Pins) differed significantly by stocking density (3-way ANOVA; $F_{2,34}=$ $4.87, \mathrm{p}<0.05$ ) but not ploidy or oyster farm location. These differences did not, however, support our hypothesis that lower stocking density oysters would have fewer worms: oysters at medium stocking density had significantly more $P$. websteri $\left(3.9 \pm 1.8 \mathrm{~cm}^{-2}\right)$ than high stocking density $\left(2.0 \pm 1.4 \mathrm{~cm}^{-2}\right)$ (post hoc Tukey test; $\mathrm{p}<0.01$ ), but neither differed from the low stocking density.

In contrast to the first (2016) deployment, farms differed in infestation consistently over the first 3 sampling dates of the second (2017) deployment, with infestation initially higher at Murder Point and Point aux Pins (Figs. 3B \& S2). However, in May 2017, infestation increased significantly in the previously less-infested farms, Navy Cove and Massacre Island, to higher abundances than the other 2 farms (Figs. 3B \& S2). Significant 2-way interactions for collection date $\times$ oyster farm location $\left(F_{9,281}=33.30, \mathrm{p}<0.001\right.$; Fig. 3B) and density $\times$ oyster farm location $\left(F_{6,281}=\right.$ $4.507, \mathrm{p}<0.001$; Fig. S3) were observed for $P$. websteri abundances for the 2017 deployment. Post hoc pairwise Tukey tests showed no effect of ploidy alone or interaction with another factor and only one significant difference among densities at a single farm. Oysters at high density had a higher abundance than both medium and low stocking densities (post hoc pairwise Tukey tests; Fig. S3). 


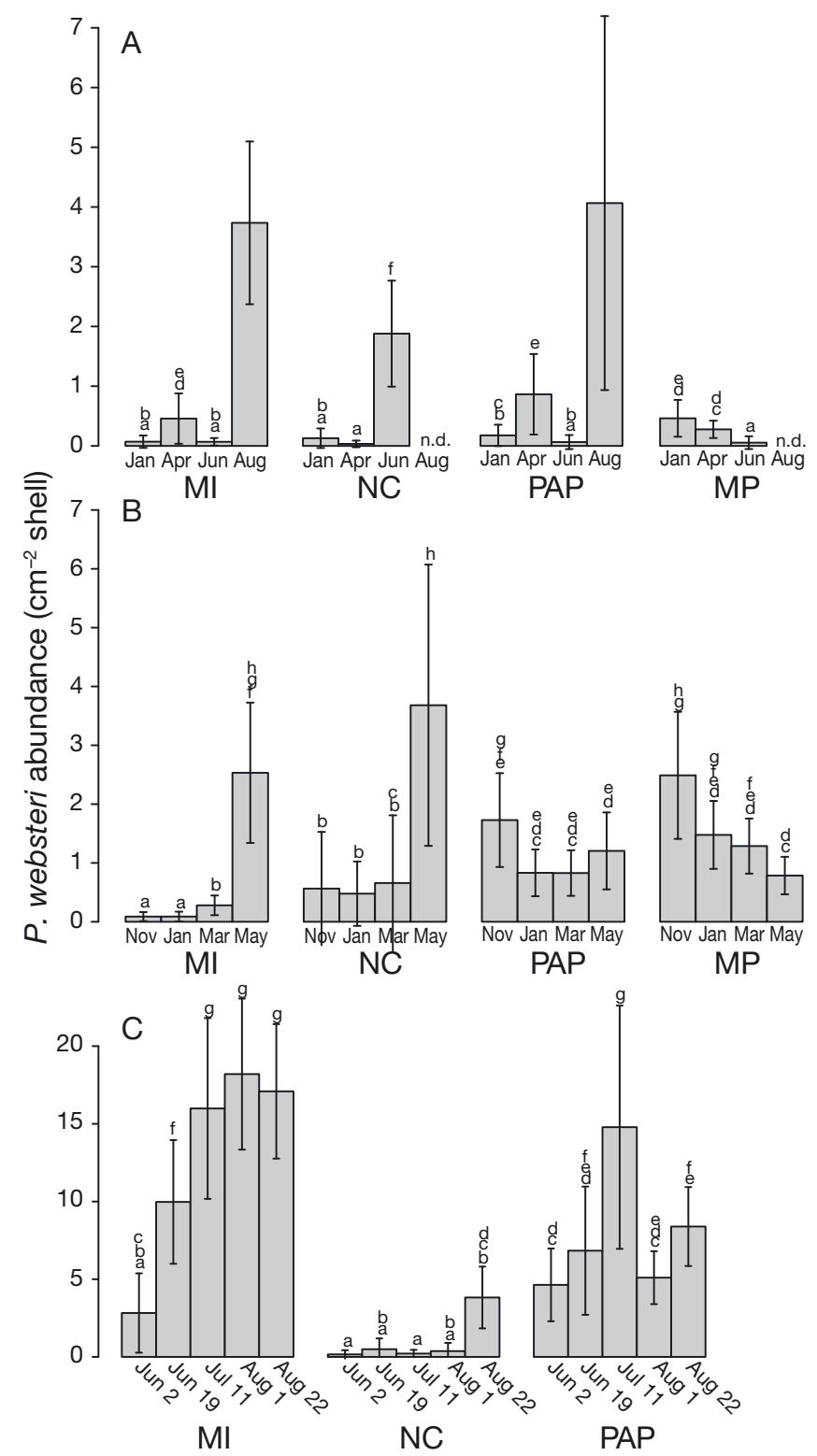

Fig. 3. Mean $( \pm \mathrm{SD})$ Polydora websteri abundance for the collection date $\times$ oyster farm location interaction during the (A) 2016 deployment $(n=4)$, (B) 2017 deployment $(n=4)$, and (C) short-term summer 2017 deployment $(n=12)$. Oyster farms abbreviated as follows: Massacre Island (MI); Murder Point (MP); Navy Cove (NC); Point aux Pins (PAP). Letters indicate significant differences (Tukey post hoc test, $\mathrm{p}<0.05$ ); lettered differences for (A) do not include August/September

Worm abundance increased substantially over the summer of 2017 at both Massacre Island and Point aux Pins but remained low through the sampling period at Navy Cove (Figs. 3C \& S2), where mortality of triploid oysters occurred between 11 July and 1 August. Significant interactions between collection date $\times$ oyster farm location $\left(F_{8,327}=29.47, \mathrm{p}<0.001\right.$; Fig. 3C), ploidy $\times$ oyster farm location $\left(F_{2,327}=3.47\right.$, $\mathrm{p}<0.05)$, and ploidy $\times$ collection date $\left(F_{4,327}=6.02\right.$, $\mathrm{p}<0.001$; Fig. S4) were observed for $P$. websteri abundance during the short-term summer deployment. Although the effect of ploidy was statistically significant, differences in ploidy either within a single farm or during a single collection date (post hoc pairwise Tukey tests; Fig. S4).

Environmental data collected during the shortterm summer 2017 deployment showed no differences between Massacre Island and Navy Cove in the mean salinity, temperature, and DO for any collection period (auto-correlated $t$-test; $p>0.05$; Fig. 4A-C). There was notable variability in the environmental data over the course of the study period, with fluctuations ranging over a broad range of time scales, i.e. daily to weekly (Fig. 4). The power spectral densities of these parameters (Fig. 4E-G) highlight the distribution of variance across frequencies present in the time series. In general, both sites had typical patterns of coastal hydrographic data with a strong discrete peak at the diurnal frequency (0.042 cycles per hour [cph] corresponds to $24 \mathrm{~h}$ ) as well as increasing energy with decreasing frequency over the low-frequency (longer period) region of the spectrum (left part of graphs Fig. 4E-G). These peaks were more pronounced for temperature and DO (Fig. 4C,G) than for salinity, consistent with increased temperature and DO during the day and decreases at night. Interestingly, the temperature and DO power spectral densities had weak peaks around $0.0083 \mathrm{cph}(\sim 12 \mathrm{~h})$, likely a higher harmonic derived from the dominant diurnal processes (tides and diel heating and cooling) in the region. The power spectrum of the salinity signal at Navy Cove showed generally higher energy levels (indicating higher variability) than the Massacre Island site, particularly around the diurnal frequency (Fig. 4E). There were only minor differences when comparing the temperature and DO signals between the sites (Fig. 4B-C, F-G). Mean DO was slightly lower at Navy Cove, but there was high variability at both sites, and since the DO only reached hypoxic conditions $\left(<2 \mathrm{mg} \mathrm{l}^{-1}\right)$ a few times and for very brief periods, it is unlikely that DO negatively affected worms or oysters at either site. The time series of turbidity data at both sites were highly nonstationary and so the quality of the power spectral densities was suspect, thus the data are not shown. Turbidity was highly variable, with distinctly different patterns at the 2 sites (Fig. 4D). Although mean values can not be directly compared (see Section 2.2), periods of higher turbidity at one site do not correspond to higher turbidity at the other. 
A

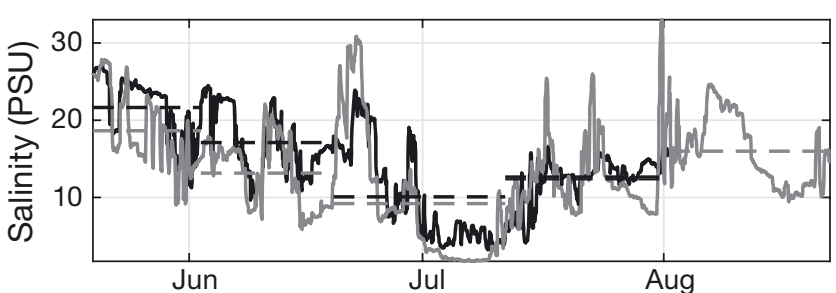

B

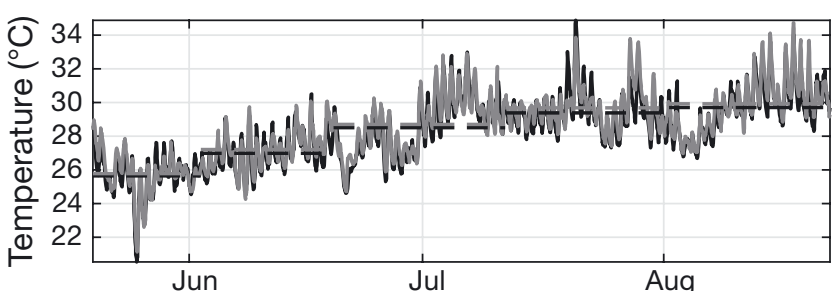

C

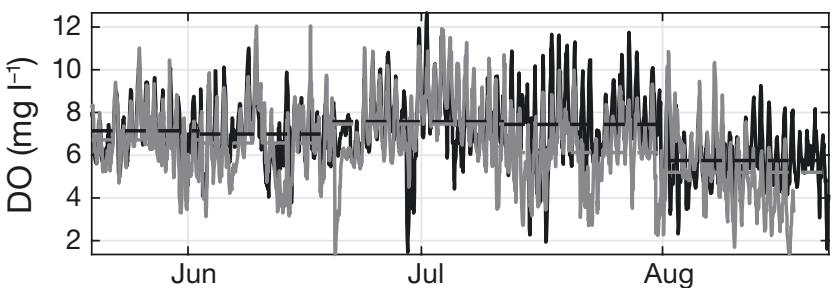

D

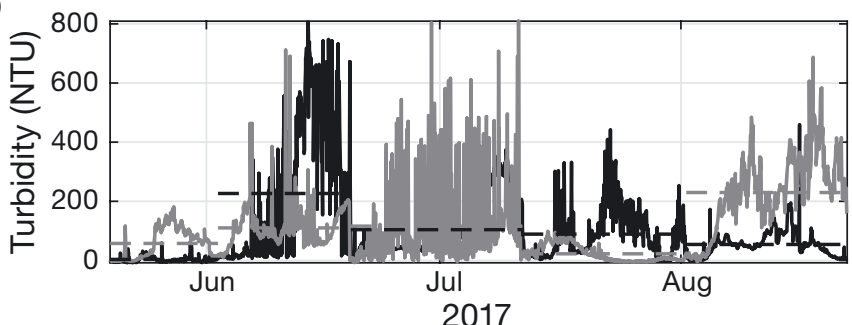

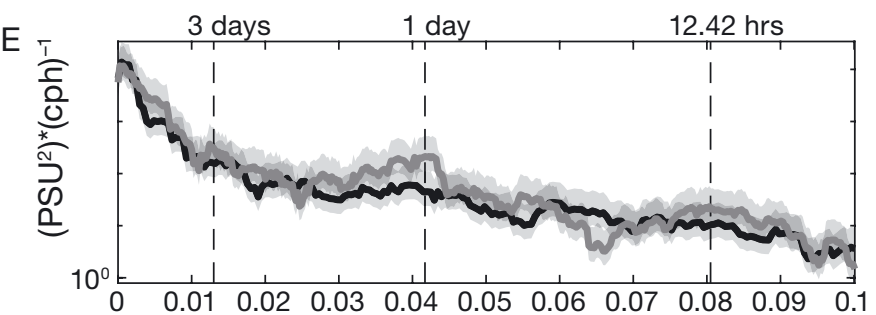

$\mathrm{F}$

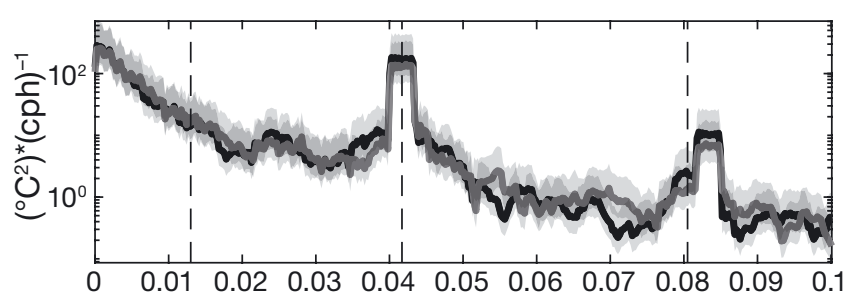

G

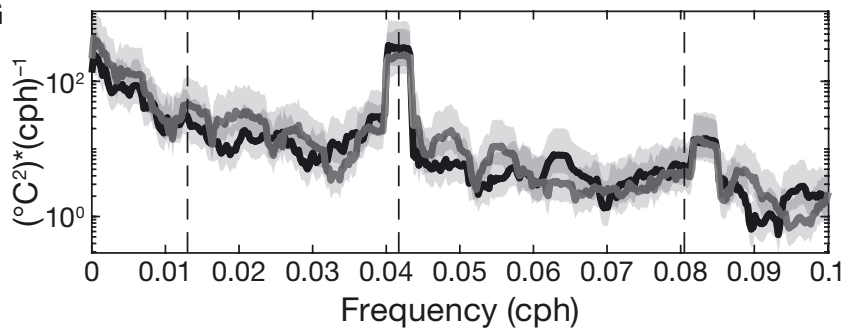

Massacre Island

Navy Cove

Fig. 4. (A-D) Hourly averaged time series and (E-G) the associated power spectral density of temperature, salinity, dissolved oxygen, and turbidity from short-term oyster deployment at Massacre Island and Navy Cove oyster farms. Sample collection period means are shown as horizontal dashed lines in (A-D). Gray shading in the power spectral density plots (E-G): 95\% CI. cph: cycles per hour

\subsection{Larval abundances}

Spionid polychaete larvae were found year-round, and abundances varied considerably (Fig. 5). Larval abundances showed a significant 3-way interaction (collection date $\times$ oyster farm location $\times$ proximity to farm; 3 -way ANOVA $F_{18,111}=3.54, p<0.001$; Fig. 5) . Although temporal patterns were largely nonsignificant, there were trends toward higher larval abundances around summer, more so at Massacre Island and Navy Cove in 2016 than the other sites (Fig. 5). All sites showed high larval abundances during May 2017. Only at Murder Point in November 2016 were adjacent larvae significantly more abundant than those away from the farm, but away samples were never significantly greater than adjacent samples at any location at any time (post hoc pairwise Tukey tests; Fig. 5). The distribution of larval sizes had a sig- nificant collection date $\times$ proximity to farm interaction (2-way Scheirer-Ray-Hare; $H_{7}=23.38, \mathrm{p}<0.01$; Fig. S5). Size distributions in August/September 2016 skewed toward smaller larvae adjacent to the farm than away, consistent with our hypothesis that farms may be a source of larvae. While this pattern seemed to be present in other seasons, this was the only sampling time in which there was a significant difference in distributions between adjacent and away samples (Fig. S5). There was no correlation between spionid larval abundance and adult $P$. websteri abundance (Kendall Tau correlation $r_{\tau}=0.20 ; p=0.93$ ).

\subsection{Condition index}

Condition index for the 2016 deployment was in some cases higher for triploids than diploids, but this 

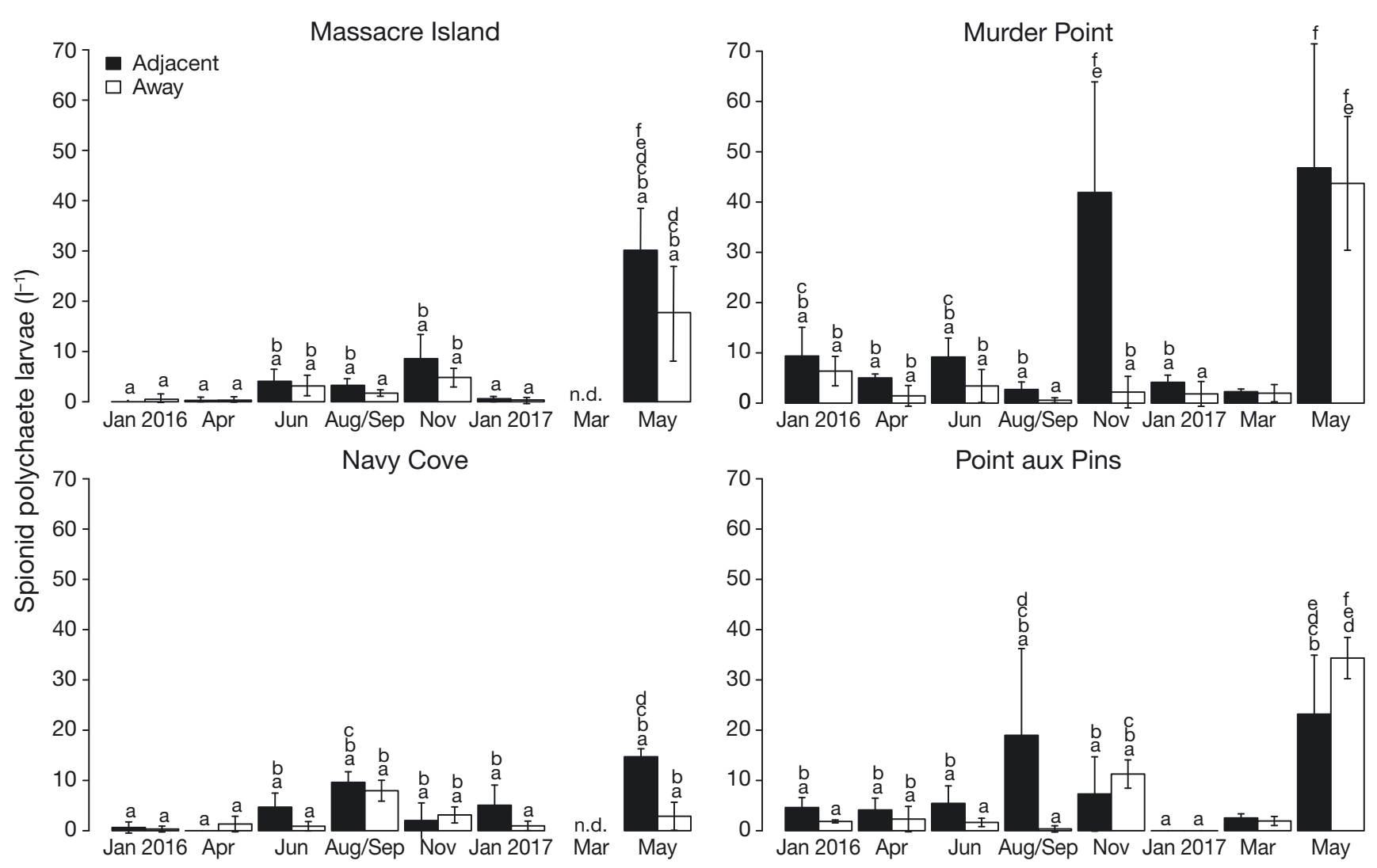

Fig. 5. Mean $( \pm \mathrm{SD})$ spionid polychaete larvae abundance $(\mathrm{n}=3)$ for the collection date $\times$ oyster farm location $\times$ proximity to farm interaction. Letters indicate significant differences (Tukey post hoc test, $\mathrm{p}<0.05$ ); lettered differences do not include March 2017, but a 2-way ANOVA for that sampling date showed no significant differences

varied among oyster farms, stocking densities, and sampling times. Significant interactions were found for density $\times$ ploidy $\times$ collection date $\left(F_{4,2133}=3.66\right.$, $\mathrm{p}<0.01$; Fig. $6 \mathrm{~A}$ ), density $\times$ ploidy $\times$ oyster farm location $\left(F_{6,2133}=2.43, \mathrm{p}<0.05\right.$; Fig. S5A $)$, and density $\times$ collection date $\times$ oyster farm location $\left(F_{12,2133}=3.63\right.$, $\mathrm{p}<0.001$; Fig. S5B). Triploid oysters had a significantly higher condition index than diploids in January at high density and in June at low and medium density, but diploid condition index was never higher than that of triploids (post hoc pairwise Tukey tests; Fig. 6A). Similarly, triploids had higher condition index than diploids for a few stocking density/farm paired comparisons (Fig. S6A). Condition index peaked in April at all farms other than Navy Cove, although differences were only significant for some stocking densities (Fig. S6B). Condition index in August/September 2016 (analyzed separately) had significant interactions: density $\times$ ploidy $\left(F_{2,228}=4.40\right.$, $\mathrm{p}<0.05$; Fig. 6B) and ploidy $\times$ oyster farm location $\left(F_{1,228}=5.36, \mathrm{p}<0.05\right)$. High-density triploids had a lower condition index than triploids at lower stocking densities, but triploids had higher condition index than diploids under all density treatments (post hoc pairwise Tukey tests; Fig. 6B). Condition indices were lower at both farms sampled in August/September than in January through June (Fig. S7).

Condition index for the 2017 deployment also showed variable ploidy effects. Significant interactions were found: ploidy $\times$ oyster farm location $\left(F_{3,1815}=3.22, \mathrm{p}<0.05\right.$; Fig. $\left.6 \mathrm{C}\right)$ and ploidy $\times$ collection date $\left(F_{3,1815}=22.54, \mathrm{p}<0.001 ;\right.$ Fig. $\left.6 \mathrm{D}\right)$. Triploid oysters had significantly greater condition index than diploids at Massacre Island and Navy Cove but not the other 2 sites (Fig. 6C). Condition index peaked in March, and for diploids decreased in May to significantly lower condition index than triploids (Figs. 6D \& S7). In both years, triploids had higher condition index than diploids at least some of the time, and condition index peaked in the spring (Figs. $6 \&$ S7).

\subsection{Effect of infestation on condition index}

In the 2016 deployment, there was a weak negative correlation between $P$. websteri abundance and condition index for diploids in June 2016 (Kendall Tau correlation; $\mathrm{r}_{\tau}=-0.17, \mathrm{p}<0.05$; Fig. 7A); but nei- 


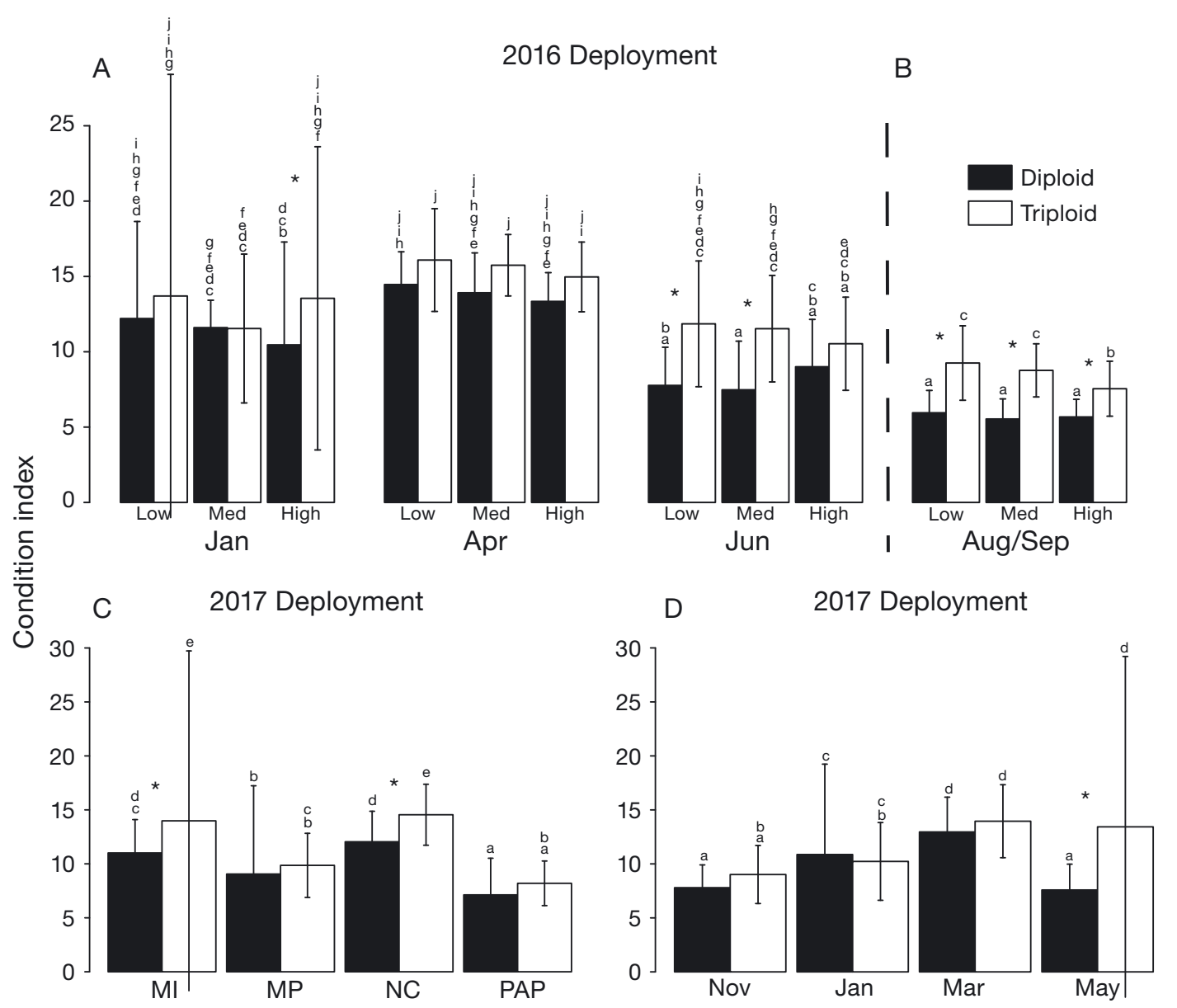

Fig. 6. Mean $( \pm \mathrm{SD})$ oyster condition index for $(\mathrm{A}) 2016$ deployment $(\mathrm{n}=13)$ density $\times$ ploidy $\times$ collection date interaction, $(\mathrm{B})$ August/September 2016 density $\times$ ploidy interaction, (C) 2017 deployment $(n=5)$ ploidy $\times$ oyster farm location interaction, and (D) 2017 deployment ploidy $\times$ collection date interaction. Letters indicate significant differences (Tukey post hoc test, $\mathrm{p}<0.05$ ); asterisks highlight paired ploidies in which triploid condition index was significantly higher that diploid

ther triploids in June, nor either ploidy during other seasons showed a significant correlation. In the 2017 deployment, negative correlations were found between $P$. websteri abundance and condition index for diploids and triploids in November 2016 (dip $\mathrm{r}_{\tau}=$ -0.34 , trip $r_{\tau}=-0.29$ ), January (dip $r_{\tau}=-0.40$, trip $r_{\tau}=$ -0.41), and March 2017 (dip $r_{\tau}=-0.37$, trip $r_{\tau}=-0.23$; all $\mathrm{p}<0.01$ ), but not for May 2017 (both $\mathrm{p}>0.9$; Fig. 7B) when worm infestation was high. Notably, no correlation was found between worm infestation and condition index for triploids in either summer (Fig. 7C).

\subsection{Re-infestation}

When $P$. websteri abundance in deployed shells was corrected for collection date, there was a significant previous infestation $\times$ oyster farm location interaction (2-way repeated measures ANOVA; $F_{2,63}=$ $7.08, \mathrm{p}<0.05$; Fig. 8). Point aux Pins was the only oys- ter farm to show differences in re-infestation based on previous infestation, and pairwise differences between previously infested and uninfested shells were only significant for one collection time (July 11) at this site (Tukey post hoc, p < 0.05) (Fig. 8). There were no differences between infested and uninfested shells at the other 2 sites. Massacre Island shells had higher re-infestation in both previously infested and uninfested shells than Navy Cove (Fig. 8), similar to differences observed in worm abundances in live oyster shells (Figs. 3C \& S2).

\subsection{Long-term variability in environmental conditions}

Average bay salinity increases as the high river discharge from spring transitions to a period of low discharge in the summer and fall (Fig. 9). The summer of 2017 showed a deviation from this trend with below-average spring discharge, then increased dis- 
A 2016 deployment

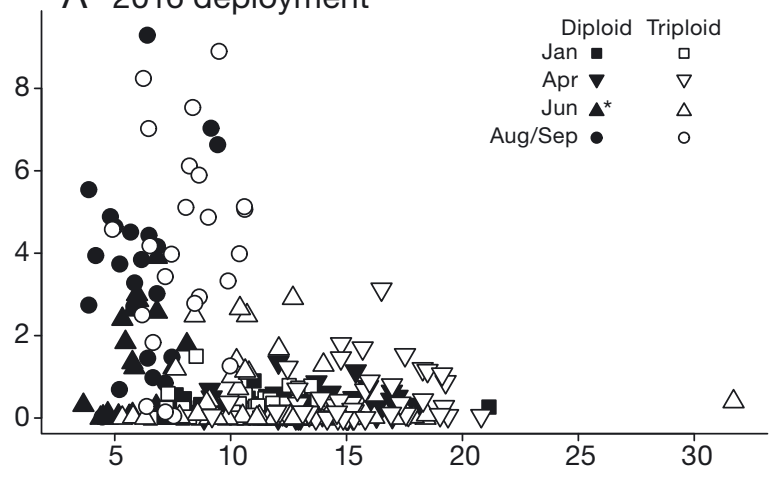

B 2017 deployment

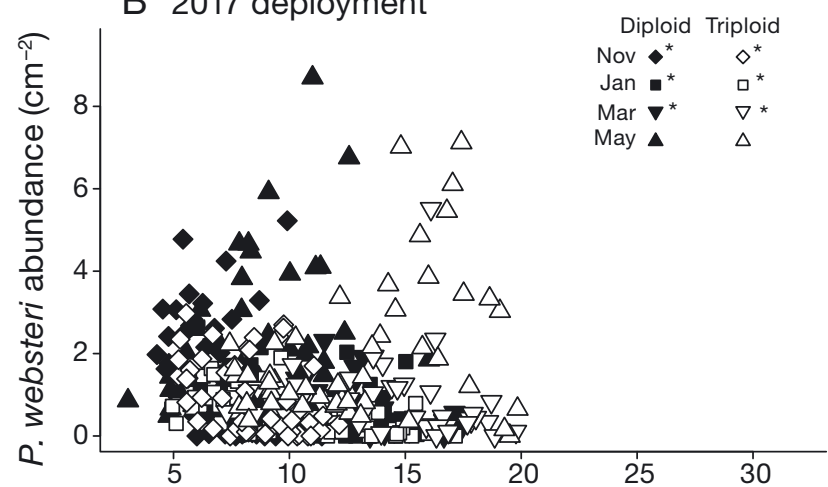

C Summer triploids

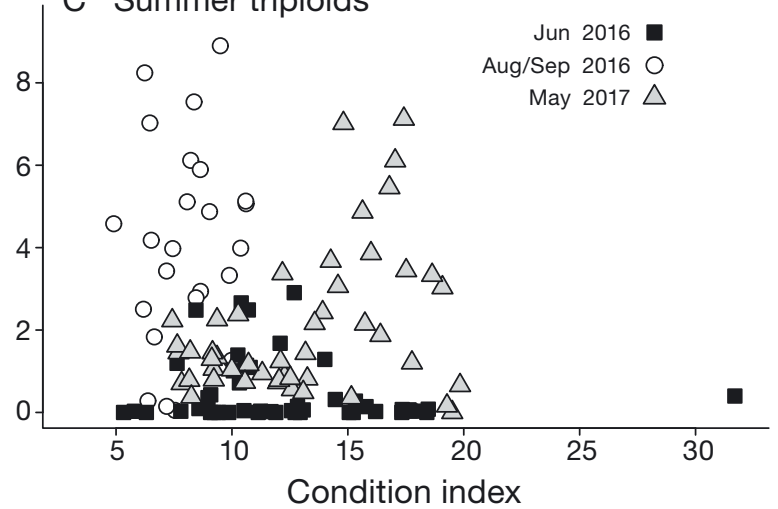

Fig. 7. Condition index versus Polydora websteri abundance for individual diploid and triploid oysters for (A) 2016 deployment collected in January ( $\mathrm{n}=48, \mathrm{n}=47$ ), April (both $\mathrm{n}=48$ ), June (both $\mathrm{n}=48$ ), and August/September 2016 ( $\mathrm{n}=$ 22, $\mathrm{n}=24)$, (B) 2017 deployment collected in November 2016 $(\mathrm{n}=47, \mathrm{n}=48)$, January $(\mathrm{n}=42, \mathrm{n}=48)$, March (both $\mathrm{n}=48)$, and May 2017 ( $\mathrm{n}=47, \mathrm{n}=48)$, and $(\mathrm{C})$ for triploid oysters collected during the summer: June $(\mathrm{n}=48)$, August/September $2016(\mathrm{n}=24)$, and May $2017(\mathrm{n}=48)$. ( $\left.{ }^{*}\right)$ in legend indicates significant relationship found

charge in mid- to late May, and a late high-discharge event in June that lowered salinity considerably (Fig. 9). Discharge in 2016 was lower than average, with salinity fluctuating around and above the mean (Fig. 9). The average salinity in July 2017 was 8.1 PSU compared with 21.8 PSU in July 2016.

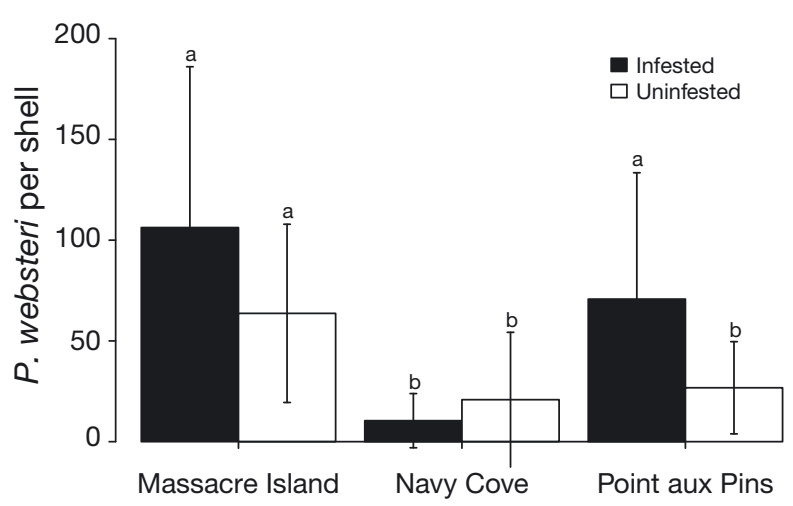

Fig. 8. Mean $( \pm \mathrm{SD})$ Polydora websteri per oyster shell $(\mathrm{n}=$ 15) of previously infested and uninfested shells deployed at Massacre Island, Navy Cove, and Point aux Pins. Letters indicate significant differences (Tukey post hoc test, $\mathrm{p}<0.05$ )

\section{DISCUSSION}

\subsection{Ploidy and stocking density}

Results of the long-term deployments showed negligible effects of either ploidy or stocking density on abundance of adult Polydora websteri (Fig. 3), in contrast to our hypothesis that higher growth rates of triploid oysters and lower stocking density would lead to lower $P$. websteri infestation (Honkoop \& Bayne 2002, Bishop \& Hooper 2005). Our results are consistent with previous studies by Davis (2013), who found no influence of stocking density on the visible number of $P$. websteri burrows from a single sampling, and Gamble (2016), who found no influence of relatively small changes in stocking density (125, 150, and 175 oysters $\mathrm{bag}^{-1}$ ) on $P$. websteri infestation over a 3 mo period. Although our results showed significant interactions among density, ploidy, and other variables (Figs. S1, S3, \& S4), these differences were largely driven by differences at individual collection dates and oyster farms, with few to no differences in worm abundance between ploidies at a single farm or collection dates. Our findings were consistent with previous studies showing that stocking density does not affect infestation, and this is one of the first studies to examine the effects of ploidy on infestation by Polydora. Practically, this implies that oyster aquaculturists can vary stocking density and/or ploidy without concern that these decisions will affect $P$. websteri infestation.

This study only examined $P$. websteri abundance, not the number of blisters or the oysters' ability to recover from infestation. Faster growth rates may not affect worm abundance but it is possible that oysters that grow faster recover more quickly and may have 


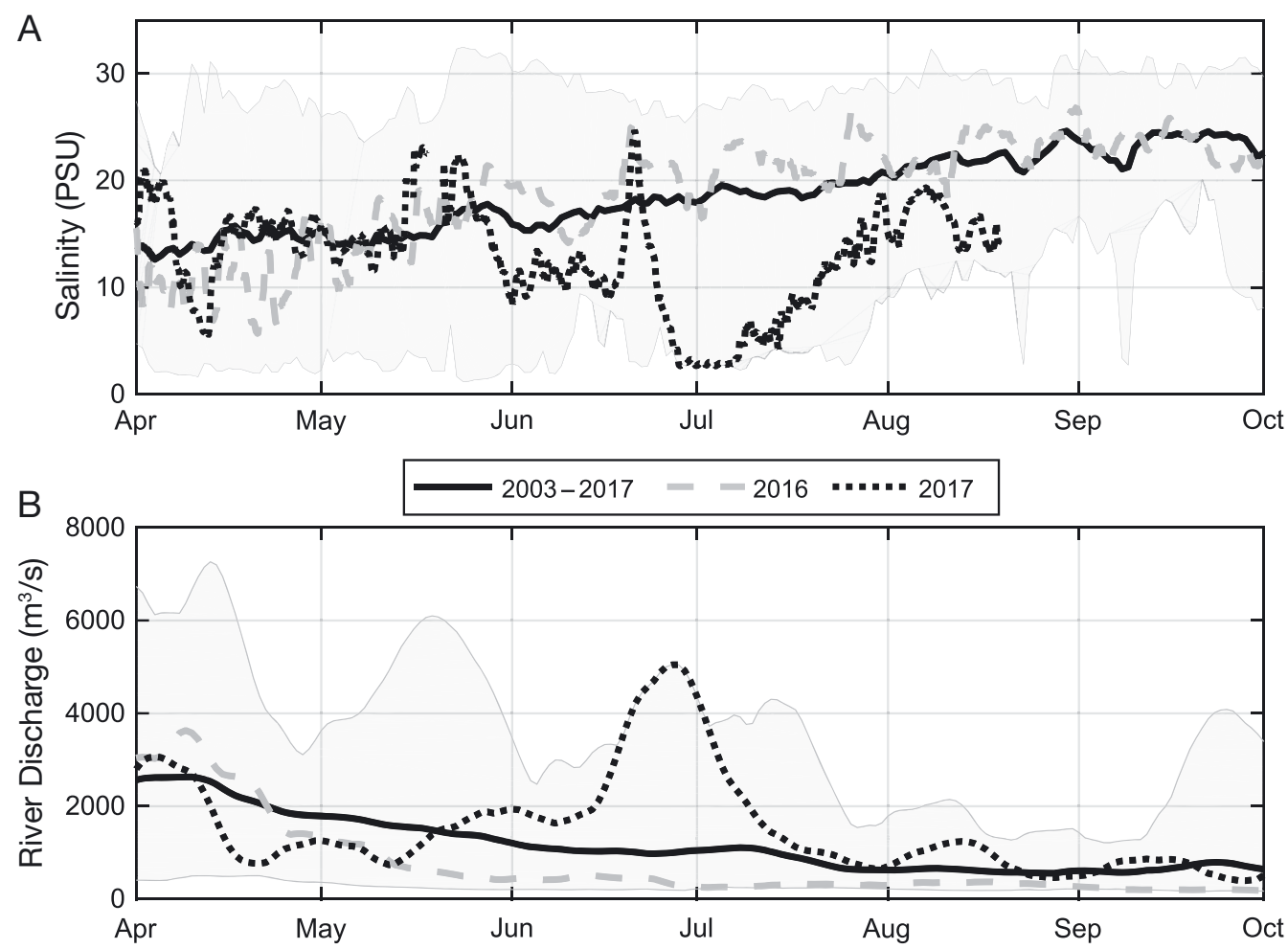

Fig. 9. (A) Subtidal salinity at Dauphin Island (DI), comparing salinity during 2016 (gray dashed line) and 2017 (black dotted line) to the average salinity over 2003-2017 (solid black line with shaded range indicating maximum and minimum). Salinity at the DI site ranged on average from 11-25 PSU. (B) River discharge into Mobile Bay from the Alabama and Tombigbee rivers over the same time periods

fewer blisters. Oysters at high stocking density may experience more stress (Bishop \& Hooper 2005), and this may compound with mechanical irritation and food competition with $P$. websteri (Wargo \& Ford 1993) to slow recovery from infestation. Likewise, triploid oysters may not only grow faster but also secrete new layers of shell more quickly, resulting in fewer mudblisters despite the same $P$. websteri abundance. We found that triploids had similar or higher condition index than diploids (Figs. 7 \& 8), consistent with previous studies (Stone et al. 2013, Walton et al. 2013). Faster growth rates suggest triploids can reach marketable size more quickly than diploids (up to 5 mo faster in one study; Nell 2002), and therefore be exposed to mudblister worms for less time. Future studies should test for differences in mudblister formation in addition to worm abundances on oysters.

\subsection{Location and temporal variability}

We found an overall peak in $P$. websteri abundance during the late spring and summer, which was more apparent during the short-term 2017 summer sampling (Figs. $3 \&$ S2), but worm abundances varied con- siderably among oyster farms and between years. High infestation during the summer is consistent with previous studies (Mackin \& Cauthron1952, Blake 1969a, Zajac 1991, Caceres-Martinez et al. 1998). Worm abundances ( $0-882$ oyster $^{-1}$ in this study) were also consistent with previous studies performed in the summer ranging from low infestation (max. 6 worms oyster $^{-1}$ ) in Baja California (Carceres-Martinez et al. 1998) and higher infestation, often exceeding 500 worms oyster ${ }^{-1}$ and up to 2000 in Louisiana (Mackin \& Cauthron 1952). Spionid larvae were also found yearround, consistent with previous findings by Hopkins (1958) of Polydora larvae year-round in coastal Louisiana. In contrast, Blake (1969a) and Handley \& Bergquist (1997) only found $P$. websteri larvae during warmer summer months, although these studies were done in areas in which water reaches much colder temperatures in winter (Maine and New Zealand).

$P$. websteri abundance differed among oyster farms, with no single farm consistently having the highest or lowest infestation (Figs. 3 \& S2). Comparison among farms was somewhat confounded by potential minor differences in how oysters were treated at each of the farms (e.g. frequency of desiccation); farmers treated our deployed oysters the same as the rest of the 
oysters on their farm. Overall, however, oysters were raised using similar gear and similar methods that are representative of commonly used methods to raise oysters in the northern Gulf of Mexico. This allowed for better representation of the oysters at each farm and potentially more useful data for farmers, as well as a more logistically feasible experiment.

\subsection{Environmental variation}

Although we predicted that environmental conditions might explain spatial patterns in worm abundance, the only difference we found among sites during summer 2017 was a slight trend toward higher variability in salinity at Navy Cove than Massacre Island (Figs. 4E \& S2). Mobile Bay is a shallow estuary that is salinity-stratified with a large river plume that causes changes in freshwater influx and flow, so displays a broad salinity range (Kim \& Park 2012). More salinity variation at Navy Cove than Massacre Island is consistent with findings by Kim \& Park (2012) that more water passes through the mouth (Main Pass; close to Navy Cove) than the Mississippi Sound (close to Massacre Island) (Fig. 2). Among-site differences in worm abundances were particularly pronounced during this time, with much higher infestation at Massacre Island than Navy Cove (Figs. 3C \& S2). A mortality event of triploid oysters occurred at Navy Cove after the 11 July sampling, possibly related to the low-salinity event in early July (Fig. 4A). Osmotic stress can also be used as a treatment against Polydora and is known to cause high worm mortality (Nel et al. 1996, Dunphy et al. 2005, Brown 2012). While it is possible that these salinity fluctuations contributed to the differences in infestation between sites, it is likely that other factors (e.g. larval transport) were more important.

Inter-annual differences in worm abundances during the summer were higher than we expected, however, and differences in river discharge and therefore in salinity between the 2 years could potentially explain the interannual differences in worm infestation (Fig. 9). Previous studies (Lunz 1941, Loosanoff \& Engle 1943, Owen 1957) found contrasting effects of mean salinity on Polydora infestation; however, they did not examine variation in salinity. Although salinity fluctuations associated with high discharge may have created stressful conditions for worms at Navy Cove, higher flux of suspended sediment and nutrients to fuel primary production may have benefitted worms at the other sites that are more protected from salinity fluctuations.

\subsection{Larval abundances}

Another possible explanation for the different patterns of worm abundance observed in the summers of 2016 and 2017 is differences in larval recruitment. Although larval abundances were variable and we could only identify larvae to the family level (Spionidae), there were significantly more larvae at Murder Point and Point aux Pins, and a trend toward higher larval abundances at Massacre Island during May 2017 preceding our summer sampling (Fig. 5). Settlement of oyster larvae in and around Mobile Bay increases from east to west as larvae are transported out of the bay and to the west (Kim et al. 2010). It seems plausible that larval source locations and transport patterns would be similar for $P$. websteri, which could explain the larval abundance patterns in May 2017 when few larvae were found at the eastern-most site, Navy Cove. This pattern is not as clear over the whole sampling period, but there were no large peaks in larval abundance at Navy Cove. Although there was no correlation between larval and adult worm abundances, it is intriguing that very few larvae were found in the away samples at Navy Cove, and very few worms were found at that site during summer 2017.

Although larval abundances were highly variable, we found comparable or higher larval abundances adjacent to oyster farms than away from the farms (Fig. 5). Larval size distributions were significantly skewed toward smaller larvae adjacent to oyster farms compared to away in August/September 2016 (Fig. S7) when abundances of adult $P$. websteri were high (Figs. 3A \& S2), which further suggests that farms may be a source of mudblister worm larvae. There are several potentially confounding factors to consider in interpreting our larval data, however. Our away distance of $\sim 50 \mathrm{~m}$ may not have been far enough from oyster farms to be outside of the oyster farm range. Tidal excursion was not considered during larval sampling, and tides may have transported larvae from the farm either towards or away from our away site. Spionidae are common in muddy habitats, so it is likely that our larval counts included species other than P. websteri, potentially contributing to this variability. Although larvae emerge as small as 3 setigers, spionids including Polydora can also brood their larvae (Strathmann 1985), and Hopkins (1958) noted the presence of $P$. websteri larvae during warmer periods in winter along the Louisiana coast and speculated that brooding occurs only when temperatures are lower. 


\subsection{Condition index}

We found no significant correlations between worm infestation and condition index in triploid oysters during the summer months when worm infestation was high (Fig. 7C). Although P. websteri abundance was negatively correlated with condition index for diploids in June 2016 (Fig. 7A,B), condition index in diploids is also affected by spawning during the summer (e.g. Nell 2002, Stone et al. 2013). We found a lower condition index for diploids than triploids particularly during the summer months (Figs. 7 \& S6), consistent with summer spawning. Our results indicate that $P$. websteri infestation has a negligible effect on oyster condition index, but we did not examine other metrics of oyster health. Chambon et al. (2007), for example, found that in the Pacific oyster Crassostrea gigas, higher Polydora infestation resulted in more frequent but shorter duration openings for ventilation, which caused oxidative stress in the oyster.

\subsection{Re-infestation}

We hypothesized that worms would re-infest shells that had been previously infested because the existing burrow holes would facilitate settling. However, when directly comparing previously infested and uninfested shell within a farm, only Point aux Pins, with intermediate infestation in oysters, had higher reinfestation in previously infested than uninfested shells (Fig. 8). Massacre Island, with high infestation in oysters (Fig. 3C), had high infestation in both previously infested and clean shells, whereas Navy cove, with low oyster infestation (Fig. 3C), had low infestation in shells as well (Fig. 8). While other studies have noted that re-infestation of Polydora burrows by other polychaetes occur (Atkins 1931, Evans 1969), this is one of the first studies suggesting that re-infestation by Polydora may occur as well.

\section{IMPLICATIONS}

Our results indicate that modifying oyster ploidy or stocking density is not a viable strategy to deter infestation by mudblister worms, at least in our study area. However, we did not examine the effects of different ploidies and stocking densities on the appearance of the blisters, and faster growth could both increase recovery from blisters and reduce time on the oyster farm, which may reduce infestation by
Polydora websteri. We suggest that farmers monitor their farms for $P$. websteri infestation more frequently during the summer (May-September) when worm abundances were highest, although both larvae and adult worms were present year-round. Higher larval abundances and smaller larval size distributions within farms suggest that oyster farms may be sources of $P$. websteri larvae, therefore desiccation treatments may reduce larval production. At intermediate levels of infestation, previously infested shells had higher infestation than clean shells, indicating another potential benefit of treating oysters early in infestation, especially if the oysters will be deployed for more than one summer. Worm infestation was much higher in 2017 when salinity was unusually low, and variability among sites was high and consistent with larval transport patterns. This highlights the need for future research on the effects of freshwater discharge on worm infestation.

Acknowledgements. We thank collaborating oyster farmers: Lane Zirlott of Murder Point Oyster, Steve Crockett and Hugh McClure of Point aux Pins LLC, Tyler Myers of Massacre Island Oyster Ranch, and Chuck Wilson of Navy Cove Oyster Farm for helping us to perform research at their farms, taking care of the oysters between collections, and sharing their observations of worm infestation. We are grateful to the many people who contributed to the deployment and collection of oysters and larvae, including Glen Chaplin and Scott Rikard from AUSL, and William ' $\mathrm{Cy}$ ' Clemo, Will Ballentine, Erin Kiskaddon, and Ryan Parker from Dauphin Island Sea Lab. Special thanks to Sarah Spellman of AUSL for not only helping deploy and collect oysters, but also processing the condition index, and to Sarah Frankenburg for performing collection of oysters, $P$. websteri extraction, and counting for a substantial portion of the 2016 deployment. We also thank Rachel Pugh who assisted during the 2017 short-term deployment through collection, $P$. websteri extraction, counting, and shell photography. This publication was supported by the US Department of Commerce's National Oceanic and Atmospheric Administration under NOAA Award NA18OAR4170080 and NA17NOS4510101 through the Mississippi-Alabama Sea Grant Consortium and the NOAA Restore Science Program, respectively. The views expressed herein do not necessarily reflect the views of any of these organizations.

\section{LITERATURE CITED}

Abbe GR, Albright BW (2003) An improvement to the determination of meat condition index for the eastern oyster, Crassostrea virginica (Gmelin 1791). J Shellfish Res 22: 747-752

Abbe GR, Sanders JG (1988) Rapid decline in oyster condition in the Patuxent River, Maryland. J Shellfish Res 7: 57-59

Atkins D (1931) On abnormal conditions of the gills in Mytilus edulis. Part II. Structural abnormalities, with a note on the method of division of the mantle cavity in 
normal individuals. J Mar Biol Assoc UK 17:489-543

Baker BJ, Mann R (1991) Sterile triploid Crassostrea virginica (Gmelin, 1791) grow faster than diploids but are equally susceptible to Perkinsus marinus. J Shellfish Res 10:445-450

Bishop MJ, Hooper PJ (2005) Flow, stocking density and treatment against Polydora spp.: influences on nursery growth and mortality of the oysters Crassostrea virginica and C. ariakensis. Aquaculture 246:251-261

Blake JA (1969a) Reproduction and larval development of Polydora from northern New England (Polychaeta: Spionidae). Ophelia 7:1-63

Blake JA (1969b) Systematics and ecology of shell-boring polychaetes from New England. Am Zool 9:813-820

Brown SW (2012) Salinity tolerance of the oyster mudworm Polydora websteri. MSc thesis, University of Maine, Orono, ME

Caceres-Martinez J, Macias-Montes de Oca P, VasquezYeomans R (1998) Polydora sp. infestation and health of the Pacific oyster Crassostrea gigas cultured in Baja California, NW Mexico. J Shellfish Res 17:259-264

* Chambon C, Legeay A, Durrieu G, Gonzalez P, Ciret P, Massabuau JC (2007) Influence of the parasite worm Polydora sp. on the behaviour of the oyster Crassostrea gigas: a study of the respiratory impact and associated oxidative stress. Mar Biol 152:329-338

* Clements JC, Bourque D, McLaughlin J, Stephenson M, Comeau LA (2017) Siltation increases the susceptibility of surface-cultured eastern oysters (Crassostrea virginica) to parasitism by the mudworm Polydora websteri. Aquacult Res 48:4707-4717

* Clements JC, Bourque D, McLaughlin J, Stephenson M, Comeau LA (2018) Wanted dead or alive: Polydora websteri recruit to both live oysters and empty shells of the eastern oyster, Crassostrea virginica. J Fish Dis 41: 855-858

Davis J (2013) Effects of basket arrangement and stocking density when using the adjustable long-line system for oyster grow-out. MSc thesis, Auburn University

Dunphy BJ, Wells RMG, Jeffs AG (2005) Polydorid infestation in the flat oyster, Tiostrea chilensis: hyposaline treatment for an aquaculture candidate. Aquacult Int 13: 351-358

Evans JW (1969) Borers in the shell of the sea scallop, Placopecten magellnnicus. Am Zool 9:775-782

Gamble CR (2016) An evaluation of the floating cage system for eastern oyster (Crassostrea virginica): aquaculture production in the north-central Gulf of Mexico. MSc thesis, Auburn University

Ghode GS, Kripa V (2001) Polydora infestation on Crassostrea madrasensis: a study on the infestation rate and eradication methods. J Mar Biol Assoc India 43:110-119

Guo X, Allen SK Jr (1994) Reproductive potential and genetics of triploid Pacific oysters, Crassostrea gigas (Thunberg). Biol Bull (Woods Hole) 187:309-318

*Haigler SA (1969) Boring mechanism of Polydora websteri inhabiting Crassostrea virginica. Am Zool 9:821-828

Handley SJ (1998) Power to the oyster: Do spionid-induced shell blisters affect condition in subtidal oysters? J Shellfish Res 17:1093-1100

Handley SJ, Bergquist PR (1997) Spionid polychaete infestations of intertidal Pacific oysters Crassostrea gigas (Thunberg), Mahurangi Harbour, northern New Zealand. Aquaculture 153:191-205

Honkoop PJC, Bayne BL (2002) Stocking density and growth of the Pacific oyster (Crassostrea gigas) and the Sydney rock oyster (Saccostrea glomerata) in Port Stephens, Australia. Aquaculture 213:171-186

Hopkins SH (1958) The planktonic larvae of Polydora websteri Hartman (Annelida, Polychaeta) and their settling on oysters. Bull Mar Sci 8:268-277

*Hyndman RJ (2013) fpp: data for 'Forecasting: principles and practice'. R package version 05. https://CRAN.Rproject.org/package=fpp (accessed 18 March 2018)

K Kim CK, Park K (2012) A modeling study of water and salt exchange for a micro-tidal, stratified northern Gulf of Mexico estuary. J Mar Syst 96-97:103-115

Kim CK, Park K, Powers SP, Graham WM, Bayha KM (2010) Oyster larval transport in coastal Alabama: dominance of physical transport over biological behavior in a shallow estuary. J Geophys Res Oceans 115:C10019

Lauckner G (1983) Diseases of Mollusca: Bivalvia. In: Kinne $\mathrm{O}$ (ed) Diseases of marine animals, Vol II. Introduction: Bivalvia to Scaphopoda. Biologische Anstalt Helogland, Hamburg, p 477-979

Lawrence DR, Scott GI (1982) The determination and use of condition index of oysters. Estuaries 5:23-27

Lewis J, Ead R, Klein R (2007) Comparisons of turbidity data collected with different instruments: report on a cooperative agreement between the California Department of Forestry and Fire Protection and USDA Forest Service. Pacific Southwest Research Station, Santa Rosa, CA

Littlewood DTJ, Wargo RN, Kraeuter JN, Watson RH (1992) The influence of intertidal height on growth, mortality, and Haplosporidium nelsoni infection in MSX mortality resistant eastern oysters, Crassostrea virginica (Gmelin, 1791). J Shellfish Res 11:59-64

Loosanoff VL (1962) Effects of turbidity on some larval and adult bivalves. Proc Gulf Caribb Fish Inst 14:80-95

* Loosanoff VL, Engle JB (1943) Polydora in oysters suspended in the water. Biol Bull (Woods Hole) 85:69-78

Lunz GR (1940) The annelid worm, Polydora, as an oyster pest. Science 92:310

Lunz GR (1941) Polydora, a pest in South Carolina oysters. J Elisha Mitchell Sci Soc 57:273-283

MacKenzie CL, Shearer LW (1959) Chemical control of Polydora websteri and other annelids inhabiting oyster shells. Proc Natl Shellfish Assoc 50:105-111

Mackin JG, Cauthron F (1952) Effect of heavy infestations of Polydora websteri Hartman on Crassostrea virginica (Gmelin) in Louisiana. Proc Natl Shellfish Assoc 1952: 14-24

Marsden JE (1992) Standard protocols for monitoring and sampling zebra mussels. Illinois Natural History Survey, Champaign, IL

Morse DL, Rawson PD, Kraeuter JN (2015) Mud blister worms and oyster aquaculture. Maine Sea Grant Publications No. 46. Maine Sea Grant, Orono

Nel R, Coetzee PS, Van Niekerk G (1996) The evaluation of two treatments to reduce mud worm (Polydora hoplura Claparède) infestation in commercially reared oysters (Crassostrea gigas Thunberg). Aquaculture 141:31-39

Nell JA (2002) Farming triploid oysters. Aquaculture 210: 69-88

Nell JA (2007) Controlling mudworm in oysters. Primefact 590. NSW Department of Primary Industries, Nelson Bay

${ }^{\circ}$ 'Shaughnessy P, Cavanaugh JE (2015) Performing $t$-tests to compare autocorrelated time series data collected from direct-reading instruments. J Occup Environ Hyg 12:743-752 
Ogle DH, Wheeler P, Dinno A (2018) FSA: fisheries stock analysis. R package version 0.8.22. https://github.com/ droglenc/FSA

Owen MH (1957) Etiological studies on oyster mortality. II. Polydora websteri Hartmann - (Polychaeta: Spionidae). Bull Mar Sci 7:35-46

Park K, Kim CK, Schroeder WW (2007) Temporal variability in summertime bottom hypoxia in shallow areas of Mobile Bay, Alabama. Estuaries Coasts 30:54-65

Pechenik JA (1999) On the advantages and disadvantages of larval stages in benthic marine invertebrate life cycles. Mar Ecol Prog Ser 177:269-297

R Core Team (2016) R: a language and environment for statistical computing. R Foundation for statistical computing, Vienna

Read GB (2010) Comparison and history of Polydora websteri and $P$. haswelli (Polychaeta: Spionidae) as mud-blister worms in New Zealand shellfish. N Z J Mar Freshw Res 44:83-100

Rice LN, Lindsay S, Rawson P (2018) Genetic homogeneity among geographically distant populations of the blister worm Polydora websteri. Aquacult Environ Interact 10: 437-446

Schneider CA, Rasband WS, Eliceiri KW (2012) NIH Image to ImageJ: 25 years of image analysis. Nat Methods 9: 671-675

Shanks AL (2009) Pelagic larval duration and dispersal distance revisited. Biol Bull (Woods Hole) 216:373-385

Simon CA, Ludford A, Wynne S (2006) Spionid polychaetes infesting cultured abalone Haliotis midae in South Africa. Afr J Mar Sci 28:167-171

Stone BW, Hadley NH, Kingsley-Smith PR (2013) Evaluating the potential growth advantage of triploid eastern oysters (Crassostrea virginica) in South Carolina relative to

Editorial responsibility: Brett Dumbauld,

Newport, Oregon, USA commercially cultured diploid native stocks. J Shellfish Res 32:647-655

Strathmann RR (1985) Feeding and nonfeeding larval development and life-history evolution in marine invertebrates. Annu Rev Ecol Syst 16:339-361

Thomson DJ (1982) Spectrum estimation and harmonic analysis. Proc IEEE 70:1055-1096

* Wadsworth P, Wilson AE, Walton WC (2019) A meta-analysis of growth rate in diploid and triploid oysters. Aquaculture 499:9-16

*Walton WC, Rikard FS, Chaplin GI, Davis JE, Arias CR, Supan JE (2013) Effects of ploidy and gear on the performance of cultured oysters, Crassostrea virginica: survival, growth, shape, condition index and Vibrio abundances. Aquaculture 414-415:260-266

Wargo RN, Ford SE (1993) The effect of shell infestation by Polydora sp. and infection by Haplosporidium nelsoni (MSX) on the tissue condition of oysters, Crassostrea virginica. Estuaries Coasts 16:229-234

WoRMS Editorial Board (2019) World register of marine species (WoRMS). www.marinespecies.org

* Ye L, Cao C, Tang B, Yao T, Wang R, Wang J (2017) Morphological and molecular characterization of Polydora websteri (Annelida: Spionidae), with remarks on relationship of adult worms and larvae using mitochondrial COI gene as a molecular marker. Pak J Zool 49:699-710

Zajac RN (1991) Population ecology of Polydora ligni (Polychaeta: Spionidae). I. Seasonal variation in population characteristics and reproductive activity. Mar Ecol Prog Ser 77:197-206

Zottoli RA, Carriker MR (1974) Burrow morphology, tube formation, and microarchitecture of shell dissolution by the spionid polychaete Polydora websteri. Mar Biol 27: 307-316

Submitted: July 9, 2019; Accepted: June 2, 2020

Proofs received from author(s): July 15, 2020 